\title{
Obesity and survival in operable breast cancer patients treated with adjuvant anthracyclines and taxanes according to pathological subtypes: a pooled analysis
}

Bella Pajares ${ }^{1 \dagger}$, Marina Pollán ${ }^{2 \dagger}$, Miguel Martín ${ }^{3}$, John R Mackey ${ }^{4}$, Ana Lluch ${ }^{5}$, Joaquín Gavila ${ }^{6}$, Charles Vogel ${ }^{7}$, Manuel Ruiz-Borrego ${ }^{8}$, Lourdes Calvo ${ }^{9}$, Tadeusz Pienkowski ${ }^{10}$, Álvaro Rodríguez-Lescure ${ }^{11}$, Miguel Angel Seguí1 ${ }^{12}$, Olivier Tredan ${ }^{13}$, Antonio Antón ${ }^{14}$, Manuel Ramos ${ }^{15}$, María del Carmen Cámara ${ }^{16}$, César Rodríguez-Martín ${ }^{16}$, Eva Carrasco ${ }^{16}$ and Emilio Alba ${ }^{1 *}$

\begin{abstract}
Introduction: Obesity is an unfavorable prognostic factor in breast cancer (BC) patients regardless of menopausal status and treatment received. However, the association between obesity and survival outcome by pathological subtype requires further clarification.
\end{abstract}

Methods: We performed a retrospective analysis including 5,683 operable BC patients enrolled in four randomized clinical trials (GEICAM/9906, GEICAM/9805, GEICAM/2003-02, and BCIRG 001) evaluating anthracyclines and taxanes as adjuvant treatments. Our primary aim was to assess the prognostic effect of body mass index (BMI) on disease recurrence, breast cancer mortality $(B C M)$, and overall mortality $(\mathrm{OM})$. A secondary aim was to detect differences of such prognostic effects by subtype.

Results: Multivariate survival analyses adjusting for age, tumor size, nodal status, menopausal status, surgery type, histological grade, hormone receptor status, human epidermal growth factor receptor 2 (HER2) status,

chemotherapy regimen, and under-treatment showed that obese patients (BMI 30.0 to 34.9) had similar prognoses to that of patients with a $\mathrm{BMl}<25$ (reference group) in terms of recurrence (Hazard Ratio $[\mathrm{HR}]=1.08,95 \%$ Confidence Interval $[\mathrm{Cl}]=0.90$ to 1.30), $\mathrm{BCM}(\mathrm{HR}=1.02,0.81$ to 1.29), and $\mathrm{OM}(\mathrm{HR}=0.97,0.78$ to 1.19). Patients with severe obesity $(\mathrm{BMI} \geq 35)$ had a significantly increased risk of recurrence $(\mathrm{HR}=1.26,1.00$ to $1.59, P=0.048), \mathrm{BCM}(\mathrm{HR}=1.32$, 1.00 to $1.74, P=0.050)$, and $\mathrm{OM}(\mathrm{HR}=1.35,1.06$ to $1.71, P=0.016)$ compared to our reference group. The prognostic effect of severe obesity did not vary by subtype.

Conclusions: Severely obese patients treated with anthracyclines and taxanes present a worse prognosis regarding recurrence, $\mathrm{BCM}$, and $\mathrm{OM}$ than patients with $\mathrm{BMI}<25$. The magnitude of the harmful effect of $\mathrm{BMI}$ on survival-related outcomes was similar across subtypes.

\footnotetext{
* Correspondence: ealbac@uma.es

${ }^{\dagger}$ Equal contributors

${ }^{1}$ Medical Oncology Department, Hospital Clínico Universitario Virgen de la

Victoria, Málaga, Spain

Full list of author information is available at the end of the article
} 


\section{Introduction}

Breast cancer $(\mathrm{BC})$ is the most frequent invasive neoplasm in women. By 2015 the annual global incidence of $\mathrm{BC}$ is estimated at 1.6 million women [1]. The incidence in Europe alone will be over 450,000 new cases, resulting in 138,000 deaths [1]. Among others, obesity is a risk factor for several types of cancer, including $\mathrm{BC}$ [2], and has recently gained special relevance due in part to the dramatic increase in the prevalence of obesity observed worldwide. In fact, if current trends continue, over $50 \%$ of the world's population will be obese by the year 2030 [3].

Recent cohort studies show that $\mathrm{BC}$ patients who are obese at diagnosis exhibit worse outcomes than their normal-weight counterparts in terms of probability of recurrence, contralateral $\mathrm{BC}$, second primary malignancies, and overall mortality (OM) [4,5]. Whereas obese women may be at risk for being diagnosed at a more advanced stage of disease than other women, multivariate analyses confirm obesity as an independent prognostic factor for risk of recurrence and survival [5]. Additionally, recently published meta-analyses confirm a negative effect of obesity on BC prognosis [5-8]. These data, however, are mostly based on cohort studies with several limitations, such as sample heterogeneity regarding tumor stage, treatment received, follow-up period, and the use of self-reported height and weight data to calculate body mass index (BMI).

The association between obesity and prognosis is also explored in several clinical trials restricted to patients with early-stage BC. These studies were in patients receiving different treatments (for example, hormone therapy, chemotherapy protocols with/without anthracyclines) and reported conflicting results [9-15]. Although most of these studies showed an increased risk of death related to obesity, in the modern era of adjuvant anthracyclines and taxanes the association between BMI and disease recurrence and/or breast cancer mortality (BCM) requires further exploration together with an examination of the magnitude of such associations by pathological subtype, that is estrogen receptor (ER)/progesterone receptor (PR)-positive/human epidermal growth factor-2 (HER2)-negative, HER2-positive, triple-negative). The pooling of data from all patients participating in four high-quality randomized clinical trials with similar treatment and follow-up protocols offers a unique opportunity to assess the influence of BMI on clinical outcomes while minimizing unexplained variability commonly found in observational studies. Thus, the aim of this study was to assess the prognostic effect of BMI on recurrence, breast cancer mortality (BCM), and overall mortality $(\mathrm{OM})$ among $\mathrm{BC}$ patients treated with adjuvant anthracyclines and taxanes, enrolled in four phaseIII Spanish Breast Cancer Research Group (GEICAM) and Breast Cancer International Research Group (BCIRG) clinical trials (GEICAM/9906, GEICAM/9805, GEICAM/
2003-02, and BCIRG 001) [16-20]. We also evaluated the prognostic role of obesity according to the different pathological $\mathrm{BC}$ subtypes as defined by immunohistochemistry.

\section{Methods}

\section{Study design and participants}

The cohort is comprised of 98\% Caucasian women (reflecting the breast cancer patient population in Spain, as most patients included in this pooled analyses were from this country) from four randomized trials that evaluated systemic adjuvant chemotherapy (CT) based on anthracyclines and taxanes for lymph node-negative and lymph node-positive operable BC. These phase III trials accrued patients between 1996 and 2008 and evaluated the following CT protocols: 1) six cycles of docetaxel, doxorubicin, and cyclophosphamide (TAC) or fluorouracil, doxorubicin, and cyclophosphamide (FAC) for highrisk node-negative patients (GEICAM/9805) [17]; 2) six cycles of fluorouracil, epirubicin, and cyclophosphamide (FEC) or four cycles of FEC followed by weekly paclitaxel for node-positive patients (GEICAM/9906) [16]; 3) six cycles of TAC or FAC for node-positive patients (BCIRG 001) [18,19]; and 4) six cycles of FAC or four cycles of FAC followed by weekly paclitaxel for nodenegative patients (GEICAM/2003-02) [20]. Chemotherapy was prescribed by actual body weight and was adjusted for obese patients in about $2 \%$ of patients (151 of 5,683 patients). After completing the CT treatment, tamoxifen, aromatase inhibitors, or the switching strategy (that is, tamoxifen followed by aromatase inhibitor) were administered for five years to patients with ER-positive and/or PRpositive tumors. Radiotherapy (RT) was mandatory after breast-conserving surgery and was administered after mastectomy, according to each institution's guidelines. These trials were conducted before the approval of adjuvant trastuzumab therapy. Further details of the trial designs and findings have been reported elsewhere [16-20].

The Institutional Review Boards at the study sites approved these trials (see Additional file 1 for a list), and the participants provided written informed consent prior to randomization. For this analysis, we excluded patients who were randomized but not included in the corresponding trial (32 patients) and those who had incomplete height or weight data ( 9 women). The final cohort consisted of 5,683 patients.

\section{Procedure}

The independent variable of interest, BMI, was calculated based on the height and weight of each participant at the start of the study. According to the World Health Organization definition, patients were classified into five BMI subgroups: underweight $\left(<18.5 \mathrm{~kg} / \mathrm{m}^{2}\right)$, normal weight (18.5 to $24.9 \mathrm{~kg} / \mathrm{m}^{2}$ ), overweight $\left(25.0\right.$ to $\left.29.9 \mathrm{~kg} / \mathrm{m}^{2}\right)$, obese $\left(30.0\right.$ to $\left.34.9 \mathrm{~kg} / \mathrm{m}^{2}\right)$ and severely obese $\left(\geq 35.0 \mathrm{~kg} / \mathrm{m}^{2}\right)$ 
[21]. Due to the small number of underweight patients, the first two groups were combined and, thus, BMI $<25 \mathrm{~kg} / \mathrm{m}^{2}$ was used as the reference category. Other variables considered included: age, menopausal status, surgery type, histology type, histological grade, tumor size, nodal status, hormone receptor, and HER2 status. We included the category, HER2 unknown, due to the high number of participants with missing data in the GEICAM/9805 study. Regarding CT, the overall dose of each drug in the corresponding regimen was compared with the theoretical dose based on the patient's estimated body weight using the real weight of the patient at enrollment [22]. As in other studies, we considered women who received a dose lower than $85 \%$ of the standard dose as undertreated [23]. Undertreatment was computed considering the initial dose (initial undertreatment) and the total amount of CT received (overall undertreatment). Toxicity was graded according to the National Cancer Institute Common Toxicity Criteria; we considered grade 3 and 4 adverse events to be clinically relevant [24].

We calculated the impact of obesity on different endpoints. Recurrence was defined as local, regional, or distant disease recurrence or the diagnosis of a second primary breast cancer, including contralateral breast tumors. In situ tumors were not considered as recurrence. $\mathrm{BCM}$ was defined as death due to $\mathrm{BC}$, and overall mortality was defined as death from any cause. To guarantee the quality and homogeneity of the follow-up data all analyses were restricted to the first 10 years after recruitment.

\section{Statistical analysis}

The Kaplan-Meier method was used to estimate survival, and the log-rank test was used to assess the possible differences between subgroups. Cox proportional hazards regression analysis was performed to assess the prognostic effect of BMI on recurrence, BCM, and OM [25]. Basic models were adjusted for the clinical trial from which data originated (study) - which also acted as a proxy for nodal involvement - and treatment regimen. Full models included additional adjustment for age, menopausal status, tumor size, histological grade, hormone receptor status, HER2 status, surgery type, and overall undertreatment (yes/no) as potential confounders. In addition, to explore the shape of the dose-response curve for BMI without assuming a linear relationship, natural splines were used in the full model, including four knots based on Harrell's recommended percentiles, namely 5\%, 35\%, 65\%, and 95\% [26]. Finally, to test the consistency of the excess risk associated with higher BMI, subgroup analyses were conducted to estimate the effect of having $\mathrm{BMI} \geq 35$ compared to $\mathrm{BMI}<25$ per category of the following variables: clinical trial, age, menopausal status, histological type, pathologic primary tumor size, nodal involvement, surgery type, hormone therapy (yes/no), undertreatment (yes/no), and pathological subtype. We report two-sided $P$-values, and $P<0.05$ was considered statistically significant. Statistical analyses were performed using STATA 12 (StataCorp LP, College Station, TX, USA).

\section{Results}

The characteristics of the patients enrolled in each trial are provided as additional material (see Additional file 2). In total, 5,683 patients from four phase III trials with complete height and weight data were analyzed in the pooled data. The median follow-up time of patients who were alive at the time of this analysis was 93.4 months (range from 0.6 to 120 ). Table 1 describes sociodemographic and clinical characteristics of the sample and illustrates the relationship between patient characteristics and BMI category. For the sole purpose of simplifying the sample description here, we combined BMI into three categories. Using $30 \mathrm{~kg} / \mathrm{m}^{2}$ as the cut off, 4,307 patients (75.8\%) were classified as non-obese (BMI <30), 945 patients (16.6\%) had BMI between 30 and 34.9 (obese) and 431 patients $(7.8 \%)$ had BMI greater than or equal to 35 (severely obese). The median age was 48 years in the nonobese patients (range 42 to 56), 56 years among obese patients (range 49 to 62 ) and 55 years among the severely obese (range 49 to 62 ). Severely obese patients were more likely to be postmenopausal, to present lymph node positivity, and to be undertreated compared to non-obese patients. Additionally, severely obese patients were less likely to present with a tumor size $<2 \mathrm{~cm}$, undifferentiated tumors, or HER2-positive tumors. Even though the prevalence of undertreatment was low, as expected in clinical trials, there were significant differences in the doses (calculated as $\mathrm{mg} / \mathrm{m}^{2}$ ) of CT between severely obese patients and non-obese patients. A higher proportion of severely obese patients received doses below $85 \%$ of the theoretical dose of CT compared with the non-obese patients $(6.0 \%$ versus $2.4 \%$ in the first dose and $15.0 \%$ versus $7.1 \%$ considering the cumulative dose, $P<0.001$ ). Patients with severe obesity were as likely to present with severe adverse events (grades 3 to 4 ) as non-obese patients (42.0\% versus $40.4 \%, P=0.498)$.

To illustrate the relationship between BMI and survival, we calculated crude Kaplan-Meier curves for recurrencefree survival, breast cancer survival and overall survival for each BMI category (Figure 1). In the Cox regression basic model (Table 2), obese patients' outcomes were not significantly different from those of the reference group (BMI18.5 to 24.9), in terms of recurrence (Hazard Ratio [HR] 0.98, 95\% CI 0.82, 1.17, $P=0.831$ ), BCM (HR 1.04, 95\% CI $0.83,1.29, P=0.757$ ), or OM (HR 1.07, 95\% CI $0.87,1.3, P=0.526)$. However, patients with severe obesity presented significantly worse outcomes in terms of BCM 
Table 1 Distribution of variables by BMI category (non-obese, obese, and severely obese women)

\begin{tabular}{|c|c|c|c|c|}
\hline & $\begin{array}{c}\text { BMI }<30.0 \\
\text { Number (\%) }\end{array}$ & $\begin{array}{c}\text { BMI } 30 \text { to } 34.9 \\
\text { Number (\%) }\end{array}$ & $\begin{array}{c}\text { BMI } \geq 35.0 \\
\text { Number (\%) }\end{array}$ & $P$-value ${ }^{a}$ \\
\hline Age at diagnosis, years & & & & $<0.001$ \\
\hline 20 to 44 & $1,473(34.2 \%)$ & $138(14.6 \%)$ & $56(13.0 \%)$ & \\
\hline 45 to 54 & $1,599(37.1 \%)$ & $284(30.1 \%)$ & $153(35.5 \%)$ & \\
\hline 55 to 64 & $932(21.6 \%)$ & $364(38.5 \%)$ & 147 (34.1\%) & \\
\hline 65 to 76 & $303(7.0 \%)$ & $159(16.8 \%)$ & 75 (17.4\%) & \\
\hline Median (percentiles 25 to 75 ) & 48 (42 to 56$)$ & 56 (49 to 62 ) & 55 (49 to 62 ) & \\
\hline Menopausal status & & & & $<0.001$ \\
\hline Postmenopausal & $1,737(40.3 \%)$ & $631(66.8 \%)$ & $293(68.0 \%)$ & \\
\hline Premenopausal & $2,570(59.7 \%)$ & $314(33.2 \%)$ & $138(32.0 \%)$ & \\
\hline Histology & & & & 0.730 \\
\hline Ductal & $3,645(84.6 \%)$ & $788(83.4 \%)$ & $376(87.2 \%)$ & \\
\hline Lobulillar & $385(8.9 \%)$ & $93(9.8 \%)$ & $32(7.4 \%)$ & \\
\hline Mixed & $46(1.1 \%)$ & $12(1.3 \%)$ & $4(0.9 \%)$ & \\
\hline Others & $230(5.3 \%)$ & $52(5.5 \%)$ & $19(4.4 \%)$ & \\
\hline Unknown & $1(0.0 \%)$ & $0(0.0 \%)$ & $0(0.0 \%)$ & \\
\hline Histological grade & & & & 0.054 \\
\hline 1 & $384(8.9 \%)$ & $81(8.6 \%)$ & $34(7.9 \%)$ & \\
\hline 2 & $1,792(41.6 \%)$ & $416(44.0 \%)$ & $196(45.5 \%)$ & \\
\hline 3 & $1,823(42.3 \%)$ & $381(40.3 \%)$ & 187 (43.4\%) & \\
\hline Unknown & $308(7.1 \%)$ & $67(7.1 \%)$ & $14(3.2 \%)$ & \\
\hline Pathologic primary tumor size & & & & $<0.001$ \\
\hline T1 & 2,192 (50.9\%) & $423(44.8 \%)$ & 179 (41.5\%) & \\
\hline $\mathrm{T} 2$ & $1,948(45.2 \%)$ & $485(51.3 \%)$ & $232(53.8 \%)$ & \\
\hline T3 & $167(3.9 \%)$ & $37(3.9 \%)$ & $20(4.6 \%)$ & \\
\hline Nodes & & & & 0.021 \\
\hline Negative & $2,278(52.9 \%)$ & $487(51.5 \%)$ & $198(45.9 \%)$ & \\
\hline Positive & $2,029(47.1 \%)$ & $458(48.5 \%)$ & $233(54.1 \%)$ & \\
\hline Estrogen receptor & & & & 0.647 \\
\hline Negative & $1,398(32.5 \%)$ & $321(34.0 \%)$ & 137 (31.8\%) & \\
\hline Positive & 2,899 (67.3\%) & $623(65.9 \%)$ & $291(67.5 \%)$ & \\
\hline Unknown & $10(0.2 \%)$ & $1(0.1 \%)$ & $3(0.7 \%)$ & \\
\hline Progesterone receptor & & & & 0.199 \\
\hline Negative & $1,654(38.4 \%)$ & $373(39.5 \%)$ & 149 (34.6\%) & \\
\hline Positive & $2,576(59.8 \%)$ & $558(59.0 \%)$ & $276(64.0 \%)$ & \\
\hline Unknown & $77(1.8 \%)$ & $14(1.5 \%)$ & $6(1.4 \%)$ & \\
\hline Human epidermal growth factor- 2 status & & & & 0.030 \\
\hline Negative & $3,036(70.5 \%)$ & $690(73.0 \%)$ & 329 (76.3\%) & \\
\hline Positive & $656(15.2 \%)$ & $123(13.0 \%)$ & $51(11.8 \%)$ & \\
\hline Unknown & $615(14.3 \%)$ & $132(14.0 \%)$ & $51(11.8 \%)$ & \\
\hline Type of surgery & & & & 0.071 \\
\hline Mastectomy & $2,021(46.9 \%)$ & $405(42.9 \%)$ & 195 (45.2\%) & \\
\hline Conservative & $2,286(53.1 \%)$ & $540(57.1 \%)$ & $236(54.8 \%)$ & \\
\hline
\end{tabular}


Table 1 Distribution of variables by BMI category (non-obese, obese, and severely obese women) (Continued)

\begin{tabular}{|c|c|c|c|c|}
\hline Hormonotherapy & & & & 0.334 \\
\hline None & $1,068(24.8 \%)$ & $256(27.1 \%)$ & $115(26.7 \%)$ & \\
\hline Yes & $3,081(71.5 \%)$ & $664(70.3 \%)$ & $300(69.6 \%)$ & \\
\hline Unknown & $158(3.7 \%)$ & $25(2.6 \%)$ & $16(3.7 \%)$ & \\
\hline Adverse events (grades 3,4 ) & & & & 0.498 \\
\hline No & $2,565(59.6 \%)$ & $578(61.2 \%)$ & $250(58.0 \%)$ & \\
\hline Yes & $1,742(40.4 \%)$ & $367(38.8 \%)$ & $181(42.0 \%)$ & \\
\hline Initial under-treatment (in the first dose) ${ }^{\mathbf{b}}$ & & & & $<0.001$ \\
\hline No & $4,205(97.6 \%)$ & $922(97.6 \%)$ & $405(94.0 \%)$ & \\
\hline Yes & $102(2.4 \%)$ & $23(2.4 \%)$ & $26(6.0 \%)$ & \\
\hline \multicolumn{5}{|l|}{ Per type of treatment ${ }^{c}$} \\
\hline Epirubicin <85\% & $5(0.5 \%)$ & $5(2.3 \%)$ & $4(4.0 \%)$ & 0.002 \\
\hline Cyclophosphamide <85\% & $12(0.3 \%)$ & $4(0.4 \%)$ & $8(1.9 \%)$ & $<0.001$ \\
\hline Fluorouracil $<85 \%$ & $8(0.2 \%)$ & $4(0.5 \%)$ & $7(2.2 \%)$ & $<0.001$ \\
\hline Doxorubicin <85\% & $4(0.1 \%)$ & $3(0.4 \%)$ & $7(2.1 \%)$ & $<0.001$ \\
\hline Docetaxel <85\% & $24(2.5 \%)$ & $5(2.4 \%)$ & $6(5.4 \%)$ & 0.199 \\
\hline Paclitaxel <85\% & $62(5.2 \%)$ & $11(4.2 \%)$ & $7(6.7 \%)$ & 0.604 \\
\hline Overall undertreatment ${ }^{\mathrm{b}}$ & & & & $<0.001$ \\
\hline No & $3,903(90.6 \%)$ & $820(86.8 \%)$ & $360(83.5 \%)$ & \\
\hline Yes & $404(9.4 \%)$ & $125(13.2 \%)$ & $71(16.5 \%)$ & \\
\hline \multicolumn{5}{|l|}{ Per type of treatment ${ }^{c}$} \\
\hline Epirubicin <85\% & $50(5.5 \%)$ & $15(6.8 \%)$ & $13(13.1 \%)$ & 0.011 \\
\hline Cyclophosphamide <85\% & $213(4.9 \%)$ & 49 (5.2\%) & $34(7.9 \%)$ & 0.032 \\
\hline Fluorouracil $<85 \%$ & $132(3.9 \%)$ & $25(3.4 \%)$ & $24(7.5 \%)$ & 0.005 \\
\hline Doxorubicin <85\% & $160(4.7 \%)$ & $40(5.5 \%)$ & $26(7.8 \%)$ & 0.040 \\
\hline Docetaxel <85\% & $117(15.8 \%)$ & 39 (18.9\%) & $10(9.9 \%)$ & 0.068 \\
\hline Paclitaxel $<85 \%$ & $159(13.3 \%)$ & $59(22.6 \%)$ & $26(25.0 \%)$ & $<0.001$ \\
\hline
\end{tabular}

${ }^{a} P$-values computed excluding women without information in the corresponding variable; ${ }^{b}$ defined as total dose received lower than $85 \%$ of the theoretical dose prescribed; ' percentages including only women receiving the corresponding type of treatment. BMI, body mass index.

(HR 1.32, 95\% CI 1.01, 1.72, $P=0.043)$ and OM (HR 1.47, 95\% CI 1.16, 1.85, $P=0.001)$. Differences in recurrence did not attain statistical significance (HR 1.14, 95\% CI $0.91,1.42, P=0.249$ ) (Table 2 and Figure 1 ). Initial undertreatment was not related to any of the endpoints of interest, and was not considered in subsequent analyses.

In fully-adjusted models (Table 3), compared to the reference group (BMI 18.5 to 24.9) obesity remained a non-significant prognostic factor, but severe obesity independently increased the risk of recurrence (HR 1.25, 95\% CI 0.99, 1.57, $P=0.052$ ), BCM (HR 1.32, 95\% CI $1.00,1.74, P=0.053$ ), and OM (HR 1.35, 95\% CI 1.06, 1.72, $P=0.016)$.

Figure 2 depicts the fully-adjusted HR dose-response curve (dark line) and upper and lower limits of the CI (lighter lines) for BMI for each of the three endpoints of interest. For OM, the dose-response curve showed higher HRs at both BMI extremes, but the 95\% CIs did not include the one only at the right end of the curve, that is, for $\mathrm{BMI} \geq 35$. BCM and recurrence results also indicated a positive dose-response relationship, but the trend was not as pronounced and failed to reach statistical significance.

Figure 3 presents the HR and 95\% CIs associated with severe obesity $(B M I \geq 35)$ for each survival outcome by the categories of each covariate, considering the different pathological BC subtypes. For these analyses, in order to increase our statistical power, BMI $<25$ was considered the reference category. These HR values were adjusted for the rest of the variables included in the full model. No statistically significant differences in the effect of severe obesity were observed per category of the other explanatory variables, but the effect seemed to be more pronounced in younger women (age $<45$ years). 


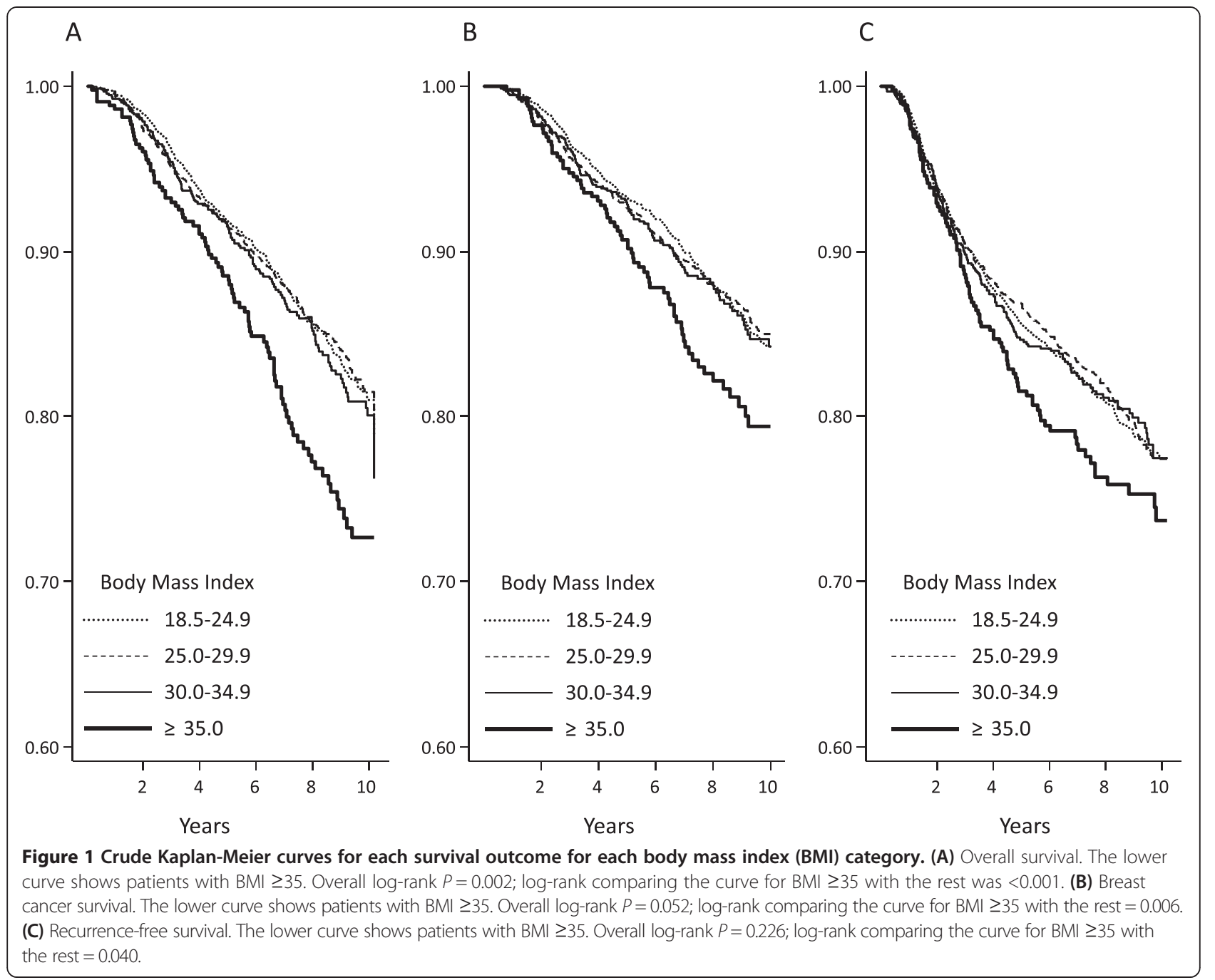

Furthermore, the magnitude of the negative effect of severe obesity on survival outcomes was similar across the three BC subtypes (ER/PR-positive/HER2-negative, HER2positive, triple-negative).

\section{Discussion}

In this retrospective survival analysis of pooled data from four large, well-conducted, randomized phase III trials of adjuvant $\mathrm{CT}$, severe obesity (BMI $\geq 35$ ) was significantly associated with worse survival outcomes (OM and $\mathrm{BCM}$ ) and a higher risk of disease recurrence. Additionally, the magnitude of the negative effect of BMI on survival was similar across pathological subtypes (ER/PRpositive/HER2-negative, HER2-positive, triple-negative). However, obese patients (BMI 30.0 to 34.9) displayed similar prognosis to patients with BMI below 25.0, not unexpected given that most studies of women participating in clinical trials show a relatively modest effect of obesity on prognosis compared with population-based studies. A recent multi-analysis [8] concluded that there was a (non- statistically significant) tendency to report higher prognostic effects of obesity in $\mathrm{BC}$ patients in observational studies than in randomized controlled trials (RCTs). In this regard, our study supports the harmful prognostic effect of severe obesity among operable $\mathrm{BC}$ patients treated with the most up-to-date CT schedules based on anthracyclines and taxanes.

To the best of our knowledge, this is the largest analysis of RCTs examining obesity as a prognostic factor in operable $\mathrm{BC}$ patients treated with anthracyclines and taxanes, and adjusting for hormone receptor and HER2 status. It is also the second study to confine significant prognostic effects to severely obese patients, supporting previous work by Dignam and colleagues [27]. In a study conducted by Berclaz et al., data from 6,792 BC patients randomized in seven trials of the International Breast Cancer Study Group from 1978 to 1993 were analyzed [9]. These trials included observation (no adjuvant therapy), endocrine therapy (tamoxifen), or cyclophosphamide, methotrexate and fluorouracil (CMF)-based CT. Their 
Table 2 Multivariate Cox proportional hazards regression analysis of effect of BMI and each study variable on overall mortality, breast cancer mortality, and recurrence in basic models (adjusted for study and treatment regimen only)

\begin{tabular}{|c|c|c|c|c|c|c|c|c|c|c|c|c|c|}
\hline \multirow[b]{2}{*}{ Variable } & \multirow[b]{2}{*}{ Number } & \multicolumn{4}{|c|}{ Overall mortality } & \multicolumn{4}{|c|}{ Breast cancer mortality } & \multicolumn{4}{|c|}{ Recurrence } \\
\hline & & Events & $\mathrm{HR}^{\mathrm{a}}$ & $95 \% \mathrm{Cl}$ & $P$-value & Events & HR & $95 \% \mathrm{Cl}$ & $P$-value & Events & HR & $95 \% \mathrm{Cl}$ & $P$-value \\
\hline \multicolumn{14}{|l|}{$\begin{array}{l}\text { Body mass } \\
\text { index, } \mathrm{k} / \mathrm{m}^{2}\end{array}$} \\
\hline$<18.5$ & 66 & 11 & 1.08 & $0.59,1.98$ & 0.796 & 9 & 1.06 & $0.54,2.06$ & 0.864 & 12 & 0.88 & $0.49,1.56$ & 0.650 \\
\hline 18.5 to 24.9 & 2,297 & 312 & 1.00 & & & 256 & 1.00 & & & 419 & 1.00 & & \\
\hline 25.0 to 29.9 & 1,944 & 265 & 0.99 & $0.84,1.16$ & 0.880 & 220 & 1.00 & $0.83,1.20$ & 0.984 & 348 & 0.95 & $0.83,1.10$ & 0.522 \\
\hline 30.0 to 34.9 & 945 & 139 & 1.07 & $0.87,1.30$ & 0.526 & 111 & 1.04 & $0.83,1.29$ & 0.757 & 173 & 0.98 & $0.82,1.17$ & 0.831 \\
\hline \multirow[t]{2}{*}{$\geq 35.0$} & 431 & 91 & 1.47 & $1.16,1.85$ & 0.001 & 68 & 1.32 & $1.01,1.72$ & 0.043 & 95 & 1.14 & $0.91,1.42$ & 0.249 \\
\hline & & & & $P$ for trend & 0.002 & & & $P$ for trend & 0.074 & & & $P$ for trend & 0.287 \\
\hline
\end{tabular}

Age at diagnosis,

years

23 to 44

45 to 54

55 to 64

65 to 76

Menopausal status

Postmenopausal

Premenopausal

Histology

Ductal

Lobular

Mixed

Others

Histological grade

2

Unknown

Pathologic primary tumor size

$\mathrm{T} 1$

T3

Estrogen receptor/ progesterone receptor

Both negative

Any of them positive

Unknown

$\begin{array}{lllll}1,667 & 276 & 1.00 & & \\ 2,036 & 228 & 0.66 & 0.55,0.78 & <0.001 \\ 1,443 & 202 & 0.92 & 0.77,1.11 & 0.380 \\ 537 & 112 & 1.41 & 1.13,1.76 & 0.002 \\ & & & P \text { for trend } & 0.030\end{array}$

$\begin{array}{lll}2,661 & 421 & 1.00\end{array}$

3022

397

$0.750 .66,0.86<0.001$

$\begin{array}{lll}4,809 & 700 \quad 1.00\end{array}$

510

364

389

$\begin{array}{llll}66 & 0.79 & 0.62,1.02 & 0.072\end{array}$

$245 \quad 1.00$

$187 \quad 0.61$

$156-0.81$

$\begin{array}{llll}76 & 1.08 & 0.83,1.39 & 0.583\end{array}$

$P$ for trend 0.655

$\begin{array}{cccc}416 & 1.00 & & \\ 296 & 0.54 & 0.47 .0 .63 & <0.001 \\ 231 & 0.66 & 0.56,0.78 & <0.001 \\ 104 & 0.81 & 0.65,1.00 & 0.049 \\ & & P \text { for trend } & <0.001\end{array}$

$322 \quad 1.00$

$\begin{array}{lllll}342 & 0.85 & 0.73, & 0.98 & 0.031\end{array}$

$461 \quad 1.00$

$\begin{array}{llll}586 & 1.05 & 0.93,1.19 & 0.415\end{array}$

Human epidermal

growth factor-2 status

Negative

4,055

Positive

$\begin{array}{lll}499 & 35 \quad 1.00\end{array}$

2,404

277

2,391

440

$2.091 .47,2.97<0.001$

$<0.001$

$571 \quad 1.00$

52

389

$\begin{array}{lllll}66 & 2.32 & 1.54,3.49<0.001\end{array}$

$\begin{array}{lll}2,794 & 249 & 1.00\end{array}$

2,665

$\begin{array}{llll}510 & 1.96 & 1.68,2.28 & <0.001\end{array}$

$\begin{array}{lllll}224 & 59 & 2.14 & 1.61,2.84 & <0.001\end{array}$

$P$ for trend $<0.001$

$\begin{array}{ccccc}1,502 & 300 & 1.00 & & \\ 4,132 & 503 & 0.49 & 0.43,0.57 & <0.001 \\ 49 & 15 & 0.77 & 0.46,1.31 & 0.338\end{array}$

$256 \quad 1.00$

$349 \quad 1.00$$$
49
$$

$4,055 \quad 518 \quad 1.00$
$194 \quad 1.00$

$417 \quad 2.03 \quad 1.71,2.41<0.001$

$53 \quad 2.39 \quad 1.76,3.25<0.001$

$P$ for trend $<0.001$
$892 \quad 1.00$

$\begin{array}{lllll}96 & 0.92 & 0.75, & 1.14 & 0.446\end{array}$

$\begin{array}{lllll}59 & 0.82 & 0.63, & 1.07 & 0.150\end{array}$

$87 \quad 2.01 \quad 1.44,2.83 \quad 0.000$

$55 \quad 1.00$

$\begin{array}{lllll}382 & 1.84 & 1.39, & 2.45 & <0.001\end{array}$

$\begin{array}{llll}523 & 2.82 & 2.13,3.72<0.001\end{array}$

$\begin{array}{llll}87 & 2.01 & 1.44,2.83<0.001\end{array}$

$349 \quad 1.00$

$\begin{array}{llll}628 & 1.78 & 1.57,2.04<0.001\end{array}$

$\begin{array}{llll}70 & 1.98 & 1.53,2.57<0.001\end{array}$

$P$ for trend $<0.001$

Unknown
$182 \quad 1.34$

$\begin{array}{llll}118 & 1.04 & 0.85,1.28 & 0.690\end{array}$ $\begin{array}{llll}394 & 0.45 & 0.38,0.53<0.001\end{array}$

$\begin{array}{llll}14 & 0.82 & 0.48,1.41 & 0.471\end{array}$

$\begin{array}{llll}679 & 0.59 & 0.51,0.67 & <0.001\end{array}$

$\begin{array}{lllll}19 & 1.00 & 0.63,1.59 & 0.998\end{array}$

$$
\begin{array}{cccccccc}
407 & 1.00 & & & 660 & 1.00 & & \\
153 & 1.42 & 1.18,1.71 & <0.001 & 223 & 1.38 & 1.18,1.61 & <0.001 \\
104 & 1.17 & 0.94,1.45 & 0.172 & 164 & 1.14 & 0.95,1.36 & 0.157
\end{array}
$$


Table 2 Multivariate Cox proportional hazards regression analysis of effect of BMI and each study variable on overall mortality, breast cancer mortality, and recurrence in basic models (adjusted for study and treatment regimen only) (Continued)

\begin{tabular}{|c|c|c|c|c|c|c|c|c|c|c|c|c|c|}
\hline \multicolumn{14}{|l|}{ Type of surgery } \\
\hline Mastectomy & 2,621 & 512 & 1.00 & & & 420 & 1.00 & & & 633 & 1.00 & & \\
\hline Conservative & 3,062 & 306 & 0.71 & $0.61,0.82$ & $<0.001$ & 244 & 0.71 & $0.60,0.83$ & $<0.001$ & 414 & 0.73 & $0.65,0.83$ & $<0.001$ \\
\hline \multicolumn{14}{|l|}{ Hormonotherapy } \\
\hline No & 1,439 & 314 & 1.00 & & & 263 & 1.00 & & & 354 & 1.00 & & \\
\hline Yes & 4,045 & 451 & 0.42 & $0.36,0.48$ & $<0.001$ & 356 & 0.39 & $0.33,0.46$ & $<0.001$ & 622 & 0.51 & $0.45,0.58$ & $<0.001$ \\
\hline Unknown & 199 & 53 & 0.79 & $0.58,1.06$ & 0.112 & 45 & 0.77 & $0.56,1.07$ & 0.120 & 71 & 1.05 & $0.81,1.37$ & 0.692 \\
\hline \multicolumn{14}{|l|}{$\begin{array}{l}\text { Initial undertreatment } \\
\text { (first dose }<85 \% \text { ) }\end{array}$} \\
\hline No & 5,532 & 648 & 1.00 & & & & & & & & & & \\
\hline Yes & 151 & 16 & 1.01 & $0.78,1.31$ & 0.932 & 16 & 1.06 & $0.64,1.75$ & 0.820 & 20 & 0.84 & $0.54,1.31$ & 0.447 \\
\hline \multicolumn{14}{|l|}{$\begin{array}{l}\text { Overall undertreatment } \\
\text { (dose }<85 \% \text { ) }\end{array}$} \\
\hline None & 5,083 & 725 & 1.00 & & & 599 & 1.00 & & & 943 & 1.00 & & \\
\hline Epirubicine $<85 \%$ & 78 & 24 & 1.55 & $1.02,2.36$ & 0.040 & 20 & 1.56 & $0.98,2.47$ & 0.059 & 25 & 1.29 & $0.86,1.93$ & 0.226 \\
\hline Cyclophosphamide <85\% & 296 & 56 & 1.28 & $0.98,1.69$ & 0.074 & 41 & 1.13 & $0.82,1.56$ & 0.446 & 63 & 1.14 & $0.88,1.47$ & 0.323 \\
\hline Fluorouracil $<85 \%$ & 181 & 33 & 1.20 & $0.84,1.70$ & 0.316 & 23 & 1.01 & $0.66,1.53$ & 0.977 & 34 & 0.98 & $0.69,1.38$ & 0.888 \\
\hline Doxorubicin <85\% & 226 & 38 & 1.30 & $0.93,1.81$ & 0.119 & 27 & 1.12 & $0.76,1.65$ & 0.576 & 42 & 1.13 & $0.82,1.54$ & 0.451 \\
\hline Docetaxel $<85 \%$ & 176 & 32 & 1.08 & $0.74,1.57$ & 0.696 & 24 & 0.96 & $0.62,1.47$ & 0.846 & 39 & 1.04 & $0.74,1.46$ & 0.814 \\
\hline Paclitaxel $<85 \%$ & 244 & 27 & 1.43 & $0.94,2.18$ & 0.092 & 16 & 1.05 & $0.62,1.78$ & 0.863 & 30 & 1.09 & $0.74,1.61$ & 0.662 \\
\hline
\end{tabular}

${ }^{a}$ Hazard ratio, $95 \% \mathrm{Cl}$ and $P$-value adjusted for study and treatment regimen.

results showed that $\mathrm{BMI}$ independently predicted $\mathrm{OM}$ $(P=0.03)$ but not risk of recurrence $(P=0.12)$. Azambuja et al. analyzed 2,887 node-positive $\mathrm{BC}$ patients included in the BIG 02-98 trial who were treated with a CT regimen based on anthracyclines. In this study, obesity emerged as an independent unfavorable prognostic factor for OM $(P=0.008)$ and recurrence $(P=0.04)$ [11]. A retrospective analysis of 4,077 women from the National Surgical Adjuvant Breast and Bowel Project clinical trials with ER-negative, node-negative $B C$, treated with several $\mathrm{CT}$ regimens with or without anthracyclines, showed higher mortality only among severely obese patients but not among obese patients [27]. Also our results are consistent with those obtained by Sparano et al. in the ECOG 1199 study [12] in which there was also a correlation between increased BMI and poorer disease-free survival and overall survival. However, in our study the correlation between $\mathrm{BMI}>35$ and worse prognosis was observed in all pathological subtypes, whereas in the ECOG 1199 this effect seemed to be limited to ER-positive patients. These differences may be due to a different definition of ER-positive status ( $>10 \%$ in ECOG 1199 versus $>1 \%$ in our studies). Furthermore, the percentage of obese patients was lower in our study (16.6 versus $36.6 \%$ respectively) and we did not include black patients. This is relevant because the ECOG
1199 has shown a significant association between black race, increased frequency of obesity and a worse prognosis in ER-positive patients [28].

Certain characteristics of our study may explain the differences between our results and previous work. First, the homogeneity of our sample, which included only patients with low comorbidity, could partially explain the stronger prognostic role of obesity observed in population-based studies than in our study. Such differences in effect may be attributed to other conditions such as diabetes, metabolic syndrome, and other chronic diseases that are associated both with obesity and with poorer prognoses. Because of the criteria used in clinical trials, obese patients with impaired health due to these conditions have a lower probability of being included in a clinical trial. Second, the assessment necessary to establish patient eligibility for a clinical trial may result in more accurate staging and consequently less confounding between obesity and delayed diagnosis often observed in obese women. Third, our results are based on a large sample size of more than 5,600 patients. Pooled analyses have shown that risk estimates based on retrospective analysis of clinical trials often decline as the sample size increases [9-11]. Finally, all our patients were treated homogeneously with anthracyclinebased CT, such an effective treatment that it may have 
Table 3 Summary of multivariate Cox proportional hazards regression analysis of effect of BMI and each study variable on overall mortality, breast cancer mortality, and recurrence in full models

\begin{tabular}{|c|c|c|c|c|c|c|c|c|c|}
\hline \multirow[b]{2}{*}{ Variable } & \multicolumn{3}{|c|}{ Overall mortality } & \multicolumn{3}{|c|}{ Breast cancer mortality } & \multicolumn{3}{|c|}{ Recurrence } \\
\hline & $\mathrm{HR}^{\mathrm{a}}$ & $95 \% \mathrm{Cl}$ & $P$-value & $\mathrm{HR}$ & $95 \% \mathrm{Cl}$ & $P$-value & $\mathrm{HR}$ & $95 \% \mathrm{Cl}$ & $P$-value \\
\hline \multicolumn{10}{|c|}{ Body mass index, $\mathrm{k} / \mathrm{m} 2$} \\
\hline$<18.5$ & 0.98 & $0.53,1.79$ & 0.945 & 0.95 & $0.48,1.85$ & 0.871 & 0.77 & $0.43,1.37$ & 0.377 \\
\hline 18.5 to 24.9 & 1.00 & & & 1.00 & & & 1.00 & & \\
\hline 25.0 to 29.9 & 0.95 & $0.80,1.12$ & 0.549 & 1.01 & $0.84,1.22$ & 0.905 & 1.03 & $0.89,1.19$ & 0.728 \\
\hline 30.0 to 34.9 & 0.98 & $0.79,1.20$ & 0.814 & 1.02 & $0.81,1.29$ & 0.860 & 1.07 & $0.89,1.29$ & 0.460 \\
\hline$\geq 35$ & 1.35 & $1.06,1.72$ & 0.016 & 1.32 & $1.00,1.74$ & 0.053 & 1.25 & $0.99,1.57$ & 0.052 \\
\hline \multicolumn{10}{|l|}{ Age } \\
\hline Per 5 years & 0.92 & $0.87,0.97$ & 0.003 & 0.86 & $0.81,0.92$ & $<0.001$ & 0.84 & $0.80,0.89$ & $<0.001$ \\
\hline \multicolumn{10}{|l|}{ Menopausal status } \\
\hline Postmenopausal & 1.00 & & & 1.00 & & & 1.00 & & \\
\hline Premenopausal & 0.60 & $0.48,0.74$ & $<0.001$ & 0.56 & $0.44,0.71$ & $<0.001$ & 0.64 & $0.53,0.77$ & $<0.001$ \\
\hline \multicolumn{10}{|c|}{ Pathologic primary tumor size } \\
\hline $\mathrm{T} 1$ & 1.00 & & & 1.00 & & & 1.00 & & \\
\hline $\mathrm{T} 2$ & 1.82 & $1.56,2.32$ & $<0.001$ & 1.87 & $1.57,2.22$ & $<0.001$ & 1.67 & $1.46,1.91$ & $<0.001$ \\
\hline T3 & 1.88 & $1.40,2.53$ & $<0.001$ & 2.07 & $1.51,2.84$ & $<0.001$ & 1.71 & $1.31,2.23$ & $<0.001$ \\
\hline \multicolumn{10}{|l|}{ Histological grade } \\
\hline 1 & 1.00 & & & 1.00 & & & 1.00 & & \\
\hline 2,3 , or unknown & 1.26 & $1.07,1.48$ & 0.006 & 1.32 & $1.10,1.58$ & 0.003 & 1.24 & $1.07,1.43$ & 0.004 \\
\hline \multicolumn{10}{|l|}{ Type of surgery } \\
\hline Mastectomy & 1.00 & & & 1.00 & & & 1.00 & & \\
\hline Conservative & 0.82 & $0.70,0.95$ & 0.008 & 0.83 & $0.70,0.98$ & 0.028 & 0.84 & $0.74,0.96$ & 0.011 \\
\hline \multicolumn{10}{|c|}{$\begin{array}{l}\text { Estrogen receptor/progesterone } \\
\text { receptor }\end{array}$} \\
\hline Both negative & 1.00 & & & 1.00 & & & 1.00 & & \\
\hline Any positive & 0.56 & $0.48,0.64$ & $<0.001$ & 0.51 & $0.44,0.60$ & $<0.001$ & 0.66 & $0.57,0.75$ & $<0.001$ \\
\hline Unknown & 0.85 & $0.51,1.44$ & 0.558 & 0.89 & $0.52,1.54$ & 0.689 & 1.10 & $0.69,1.75$ & 0.699 \\
\hline \multicolumn{10}{|c|}{$\begin{array}{l}\text { Human epidermal growth } \\
\text { factor-2 status }\end{array}$} \\
\hline Negative & 1.00 & & & 1.00 & & & 1.00 & & \\
\hline Positive & 1.19 & $1.00,1.42$ & 0.048 & 1.23 & $1.01,1.49$ & 0.037 & 1.23 & $1.05,1.44$ & 0.009 \\
\hline Unknown & 1.00 & $0.82,1.23$ & 0.965 & 1.11 & $0.89,1.38$ & 0.361 & 1.09 & $0.91,1.30$ & 0.335 \\
\hline \multicolumn{10}{|l|}{ Undertreatment } \\
\hline None & 1.00 & & & 1.00 & & & 1.00 & & \\
\hline Epirubicine $<85 \%$ & 2.36 & $1.18,4.72$ & 0.015 & 3.06 & $1.47,6.36$ & 0.003 & 1.84 & $0.93,3.63$ & 0.078 \\
\hline Cyclophosph <85\% & 0.86 & $0.35,2.13$ & 0.74 & 0.93 & $0.34,2.53$ & 0.880 & 1.31 & $0.58,2.95$ & 0.519 \\
\hline Fluorouracil <85\% & 0.64 & $0.30,1.34$ & 0.235 & 0.45 & $0.19,1.07$ & 0.069 & 0.50 & $0.26,0.99$ & 0.046 \\
\hline Doxorubicin <85\% & 1.86 & $0.89,3.88$ & 0.097 & 1.86 & $0.82,4.22$ & 0.134 & 1.29 & $0.63,2.64$ & 0.478 \\
\hline Docetaxel <85\% & 0.84 & $0.46,1.53$ & 0.559 & 0.70 & $0.35,1.40$ & 0.315 & 0.75 & $0.44,1.28$ & 0.294 \\
\hline Paclitaxel <85\% & 1.37 & $0.90,2.09$ & 0.147 & 1.06 & $0.62,1.81$ & 0.824 & 1.15 & $0.78,1.70$ & 0.491 \\
\hline
\end{tabular}

Models were adjusted for all the other variables in the table. ${ }^{2}$ Hazard ratio, $95 \% \mathrm{Cl}$ and $P$-value adjusted for study, treatment regimen and the rest of variables in the table. 


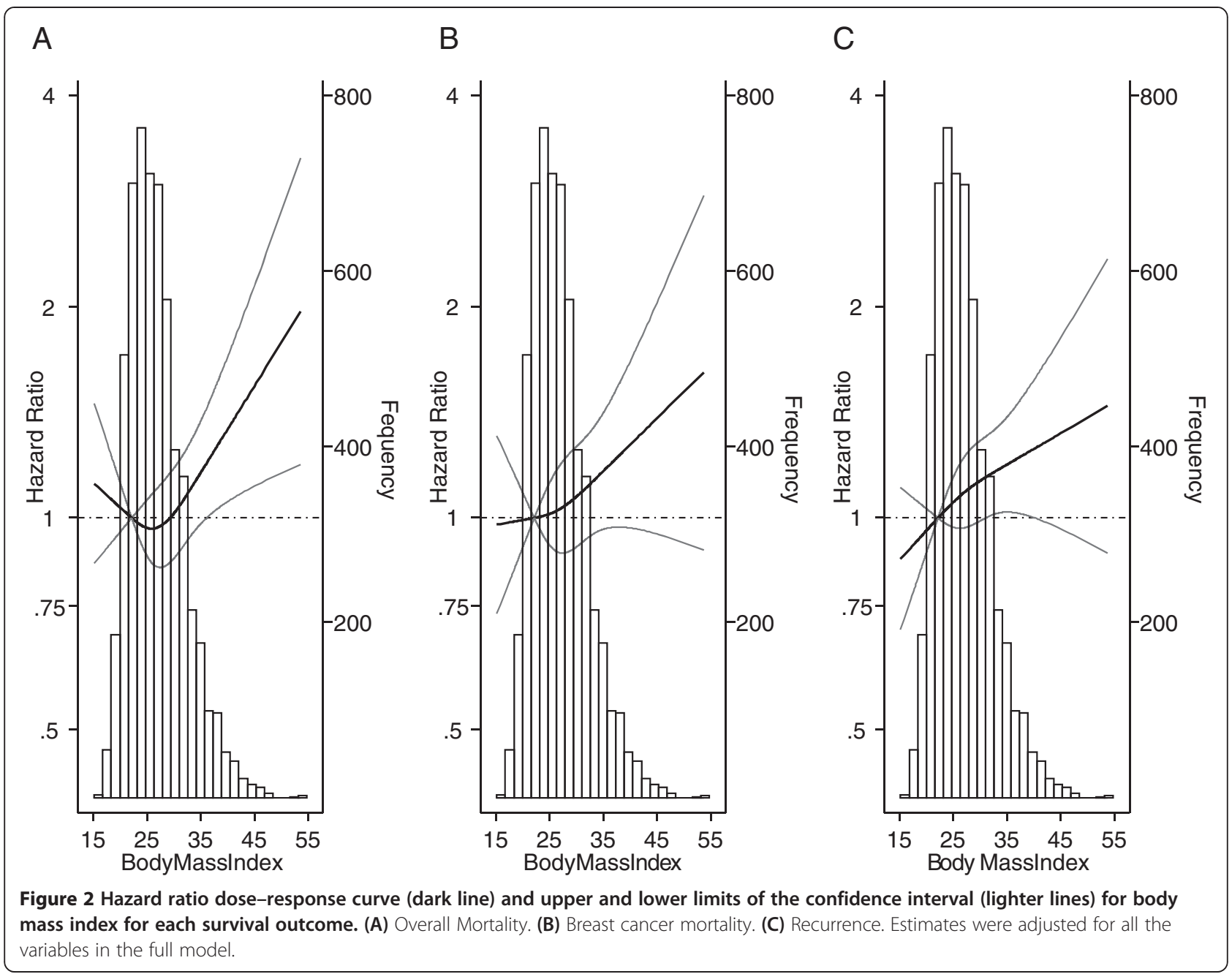

partly counteracted the adverse prognostic effect of obesity when compared to the obesity effect found in population and cohort studies, or even in clinical trials with suboptimal CT schedules like CMF. It should also be anticipated that undertreatment is less frequent when patients are treated within the context of a clinical trial.

In fact, undertreatment may also contribute to poorer survival rates in obese BC patients [22,29]. Several studies have shown that obese $\mathrm{BC}$ patients are more likely to receive reduced doses of $\mathrm{CT}$ compared to normal-weight women $[22,29,30]$. Obese patients treated with CMFbased CT were significantly more likely to receive a lower CT dose for the first course $(<85 \%$ of expected dose) than those with normal or intermediate BMI values $(39 \%$ versus $16 \%, P<0.0001)$ and this undertreatment was associated with a significantly worse outcome for ER-negative patients [27]. However, several studies found that obese women receiving full doses of CT did not experience more toxicity than normal-weight patients [22,30,31]. In our study, although undertreatment was generally low, severely obese patients were also more likely to be undertreated, despite the prevalence of serious adverse events being similar to that observed in non-obese patients. Even in the context of a clinical trial, severely obese patients were almost three times more likely to receive suboptimal doses from the start, and this insufficient dose was maintained in subsequent cycles in more than $90 \%$ of cases. Oncologists should be aware of the importance of prescribing full weight-based doses in agreement with the recommendations of the American Society of Clinical Oncology [22].

The pathways involved in the relationship between obesity and $\mathrm{BC}$ outcomes remain unclear, but obesity is known to affect several hormones and growth factors that are potentially associated with $\mathrm{BC}$ [32]. Consequently, obese patients may have elevated tumor cell proliferation and metastasis due to undefined adipokine effects on tumor cells [33]. For instance, hyperinsulinism has been correlated with $\mathrm{BMI}$, recurrence, and $\mathrm{BCM}$, regardless of hormone receptor status [34]. The pro-angiogenic and pro-inflammatory adipokines such as leptin, IL6, TNF- $\alpha$, and vascular endothelial growth factor (VEGF), secreted 


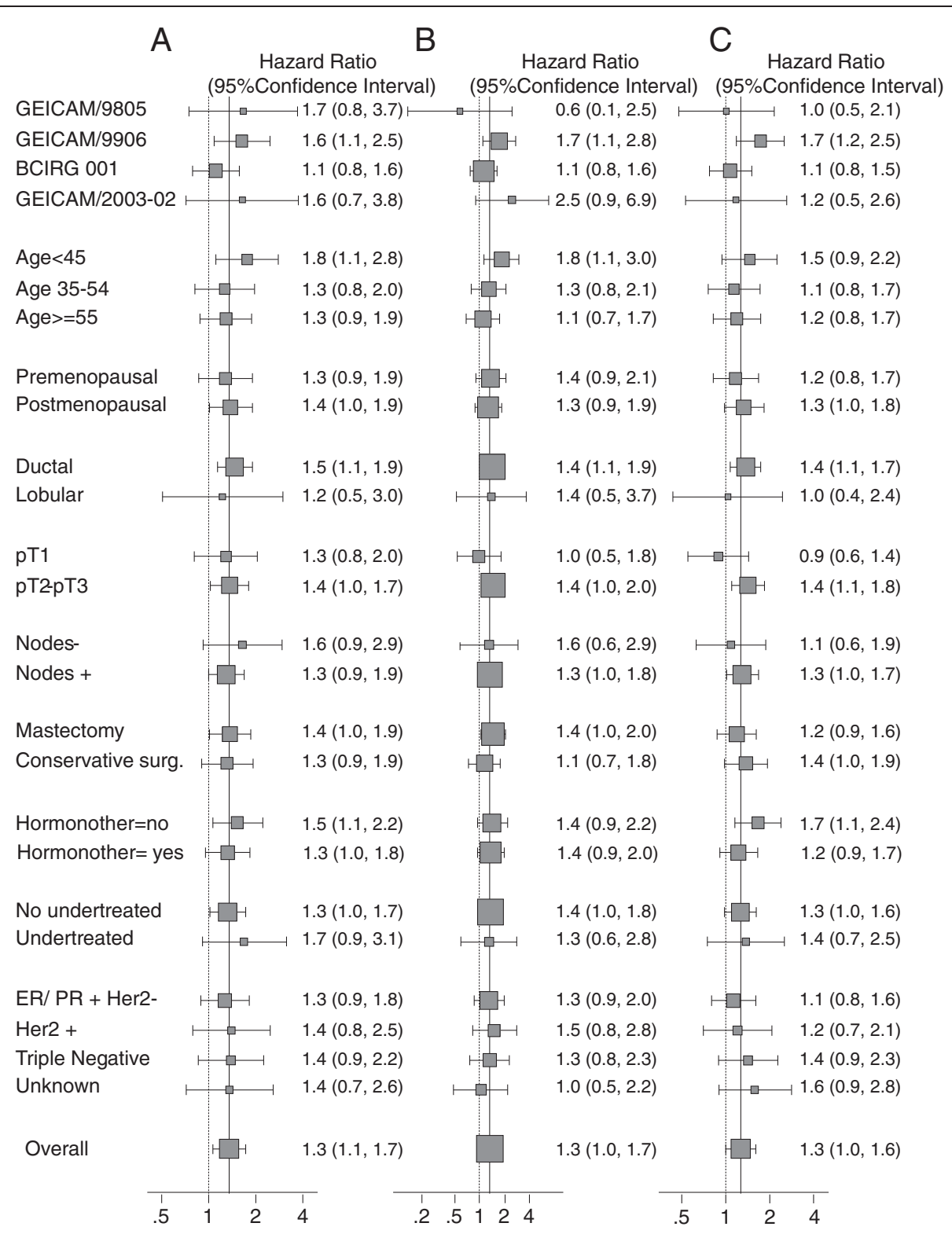

Figure 3 Hazard ratios and $95 \% \mathrm{Cl}$ associated with severe obesity (body mass index $\geq 35$ ) compared to the reference group (body mass index $<25$ ) for each survival outcome by the categories of each covariate. (A) Overall mortality. (B) Breast cancer mortality. (C) Recurrence estimates were adjusted for all the variables in the full model. The size of the interval and the box are proportional to the amount of information available per stratum. GEICAM, Spanish Breast Cancer Research Group; BCIRG, Breast Cancer International Research Group; pT, pathologic primary tumor size; surg, surgery; HER2: human epidermal growth factor-2; ER, estrogen receptor; PR, progesterone receptor.

by fat tissue, are commonly elevated in obese patients [35,36]. As BMI is directly related to circulating estrogen levels, the production of estrogens by adipose tissue has also been postulated as a factor in the more biologically aggressive ER-positive tumors in postmenopausal women [37]. Also higher rates of angiolymphatic invasion among obese women with breast cancer may contribute to their poorer outcomes, as described by Gillespie et al. in their retrospective series [38].
Several studies have evaluated the role of obesity as a risk factor for $\mathrm{BC}$ development according to different $\mathrm{BC}$ subtypes [39-42]. However, data on the role of obesity on patient prognosis according to these subtypes are scarce. A recent meta-analysis found no evidence of the prognostic role of obesity varying by hormone receptor status [7], although HER2 receptor data were not available until recently. In fact, a study on 4,770 operable $\mathrm{BC}$ patients treated with a CT regimen based 
on anthracyclines and taxanes reported a worse outcome specifically in hormone receptor-positive/HER2-negative disease patients, but not among patients with HER2positive or triple-negative disease [12]. In contrast, our analyses failed to detect a difference in the observed prognostic role of severe obesity by subtype.

Although the shortcomings of our study are not uncommon in retrospective analyses of clinical trials, our results should be interpreted in the context of the study limitations. BMI was measured only at the beginning of follow up and further changes were not considered, in part due to the difficulty in assessing changes influenced by $\mathrm{CT} /$ hormone treatment side effects. For the analysis by tumor subtype, hormone receptor positivity was assessed in each trial under the available criteria at that moment, and the lack of information on HER2 in the GEICAM/9805 trial substantially decreases the statistical power of the analyses. Major strengths of this study include a large sample size $(n>5,600)$, precise BMI information at baseline, and a standardized CT treatment based on the most active drugs in the adjuvant setting available at that time (anthracyclines and taxanes).

In summary, this study shows that obesity (BMI 30.0 to 34.9) is not associated with worse survival outcomes in operable $\mathrm{BC}$ patients treated with anthracycline- and taxane-based CT. Severely obese patients (BMI $\geq 35.0$ ), however, present an increased risk of recurrence, BCM, and $\mathrm{OM}$ compared to patients with BMI <25.0. Further, the magnitude of the negative effect of BMI on survival outcomes was similar across pathological BC subtypes.

\section{Conclusions}

Based on a large retrospective analysis of four randomized clinical trials of operable $\mathrm{BC}$ patients treated with anthracyclines and taxanes, and adjusting for hormone receptor and HER2 status, we found that severe obesity, but not obesity, emerged as a statistically and clinically significant unfavorable prognostic factor regardless of $\mathrm{BC}$ subtype. These findings support further basic and clinical research on the mechanisms of the association between severe obesity and survival outcomes in BC patients in order to maximize treatment benefits among these patients.

\section{Additional files}

Additional file 1: List of Institutional Review Boards.

Additional file 2: Characteristics of women enrolled in the four clinical trials.

\section{Abbreviations}

BC: Breast cancer; BCIRG: Breast Cancer International Research Group; BCM: Breast cancer mortality; BMI: Body mass index;

CMF: Cyclophosphamide, methotrexate, fluorouracil; CT: Chemotherapy;

ER: Estrogen receptor; FAC: Fluorouracil, doxorubicin, cyclophosphamide;
FEC: Fluorouracil, epirubicin, and cyclophosphamide; GEICAM: Spanish Breast Cancer Research Group; HER2: Human epidermal growth factor-2; HR: Hazard ratio; OM: Overall mortality; PR: Progesterone receptor; RCT: Randomized controlled trial; RT: Radiotherapy; TAC: Docetaxel, doxorubicin, cyclophosphamide; TNF: Tumor necrosis factor.

\section{Competing interests}

All authors declare that they have no competing interests.

\section{Authors' contributions}

$B P, M P$, and EA conceived the study. MM, JRM, AL, JG, CV, MRB, LC, TP, $A R L, M A S, O T, A A, M R, M C C, C R M, E C$ and EA contributed to data collection. MP analyzed the data. BP and MP interpreted the results and wrote the first draft. All authors contributed to the writing and editing of the manuscript and approved the final version. EA had full access to all the data in the study and had final responsibility for the decision to submit for publication.

\section{Acknowledgments}

This work was supported by the Spanish Breast Cancer Research Group (Grupo Español de Investigación de Cáncer de Mama) (GEICAM). No funding was received for the data analyses or the writing of this manuscript. Clinical trials GEICAM/9805 and BCIRG 001 were funded by Sanofi Aventis. GEICAM/ 9906 and GEICAM/2003-02 were partially funded by Bristol-Myers Squibb.

These funding bodies were not involved in the collection and interpretation of the data or in the decision to publish. EA and MM were also supported by FEDER (RECTICC-RD12/0036/0076). We thank all the participating patients, clinicians, GEICAM and local research staff. We thank Hosanna Soler Vila, PhD, who provided medical writing services on behalf of GEICAM.

\section{Author details}

${ }^{1}$ Medical Oncology Department, Hospital Clínico Universitario Virgen de la Victoria, Málaga, Spain. ${ }^{2}$ Epidemiology Nacional Center, Instituto de Salud Carlos III, Madrid, Spain. ${ }^{3}$ Medical Oncology Department, Instituto de Investigación Sanitaria Gregorio Marañón, Universidad Complutense, Madrid, Spain. ${ }^{4}$ Medical Oncology Department, Medical Cross Cancer Institute, Edmonton, AB, Canada. ${ }^{5}$ Hematology-Oncology Department, Hospital Clínico Universitario de Valencia- INCLIVA Health Research Institute, University of Valencia, Valencia, Spain. ${ }^{6}$ Medical Oncology Department, Instituto Valenciano de Oncología, Valencia, Spain. ${ }^{7}$ Medical Oncology Department, Sylvester Comprehensive Cancer at Deerfield; Miller School of Medicine; Univ. of Miami- Deerfield Bch, Miami, FL, USA. ${ }^{8}$ Medical Oncology Department, Hospital Virgen del Rocío, Sevilla, Spain. ${ }^{9}$ Medical Oncology Department, Complejo Hospitalario Universitario de A Coruña, A Coruña, Spain. ${ }^{10}$ Medical Oncology Department, European Health Center, Otwock, Poland. ${ }^{11}$ Medical Oncology Department, Hospital General Universitario de Elche, Alicante, Spain. ${ }^{12}$ Medical Oncology Department, Corporación Sanitaria Parc Taulí, Sabadell, Spain. ${ }^{13}$ Medical Oncology Department, Centre Léon Bérard, Lyon, France. ${ }^{14}$ Medical Oncology Department, Hospital Miguel Servet, Zaragoza, Spain. ${ }^{15}$ Medical Oncology Department, Centro Oncológico de Galicia, A Coruña, Spain. ${ }^{16}$ Spanish Breast Cancer Research Group, GEICAM, Madrid, Spain.

Received: 27 March 2013 Accepted: 16 October 2013

Published: 6 November 2013

\section{References}

1. Ferlay J, Shin HR, Bray F, Forman D, Mathers C, Parkin DM: GLOBOCAN 2008 v2.0, cancer incidence and mortality worldwide: iarc cancer base No. 10. Lyon, France: International Agency for Research on Cancer; 2010 [http://globocan.iarc.fr]

2. Renehan AG, Tyson M, Egger M, Heller RF, Zwahlen M: Body-mass index and incidence of cancer: a systematic review and meta-analysis of prospective observational studies. Lancet 2008, 371:569-578.

3. Kelly T, Yang W, Chen CS, Reynolds K, He J: Global burden of obesity in 2005 and projections to 2030. Int J Obes (Lond) 2008, 32:1431-1437.

4. Ewertz M, Jensen MB, Gunnarsdottir KA, Højris I, Jakobsen EH, Nielsen D, Stenbygaard LE, Tange UB, Cold S: Effect of obesity on prognosis after early-stage breast cancer. J Clin Oncol 2011, 29:25-31. 
5. Majed B, Moreau T, Senouci K, Salmon RJ, Fourquet A, Asselain B: Is obesity an independent prognosis factor in woman breast cancer? Breast Cancer Res Treat 2008, 111:329-342.

6. IOM (Institute of Medicine): The role of obesity in cancer survival and recurrence: Workshop summary. Washington, DC: The National Academies Press; 2012.

7. Niraula S, Ocana A, Ennis M, Goodwin PJ: Body size and breast cancer prognosis in relation to hormone receptor and menopausal status: a meta-analysis. Breast Cancer Res Treat 2012, 134:769-781.

8. Protani M, Coory M, Martin JH: Effect of obesity on survival of women with breast cancer: systematic review and meta-analysis. Breast Cancer Res Treat 2010, 123:627-635.

9. Berclaz G, Li S, Price KN, Coates AS, Castiglione-Gertsch M, Rudenstam CM, Holmberg SB, Lindtner J, Erien D, Collins J, Snyder R, Thürlimann B, Fey MF, Mendiola C, Werner ID, Simoncini E, Crivellari D, Gelber RD, Goldhirsch A: International breast cancer study group: body mass index as a prognostic feature in operable breast cancer: the International breast cancer study group experience. Ann Oncol 2004, 15:875-884.

10. Dignam JJ, Wieand K, Johnson KA, Fisher B, Xu L, Mamounas EP: Obesity, tamoxifen use, and outcomes in women with estrogen receptor-positive early-stage breast cancer. J Natl Cancer Inst 2003, 95:1467-1476.

11. de Azambuja E, McCaskill-Stevens W, Francis P, Quinaux E, Crown JP, Vicente M, Giuliani R, Nordenskjöld B, Gutiérez J, Andersson M, Vila MM, Jakesz R, Demol J, Dewar J, Santoro A, Lluch A, Olsen S, Gelber RD, Di Leo A, PiccartGebhart M: The effect of body mass index on overall and disease-free survival in node-positive breast cancer patients treated with docetaxel and doxorubicin-containing adjuvant chemotherapy: the experience of the BIG 02-98 trial. Breast Cancer Res Treat 2010, 119:145-153.

12. Sparano JA, Wang M, Zhao F, Stearns V, Martino S, Ligibel JA, Perez EA, Saphner T, Wolff AC, Sledge GW Jr, Wood WC, Fetting J, Davidson NE: Obesity at diagnosis is associated with inferior outcomes in hormone receptor-positive operable breast cancer. Cancer 2012, 118:5937-5946.

13. Sestak I, Distler W, Forbes JF, Dowsett M, Howell A, Cuzick J: Effect of body mass index on recurrences in tamoxifen and anastrozole treated women: an exploratory analysis from the ATAC trial. J Clin Oncol 2010, 28:3411-3415.

14. Ewertz M, Gray KP, Regan MM, Ejlertsen B, Price KN, Thürlimann B, Bonnefoi H, Forbes JF, Paridaens RJ, Rabaglio M, Gelber RD, Colleoni M, Láng I, Smith IE, Coates AS, Goldhirsch A, Mouridsen HT: Obesity and risk of recurrence or death after adjuvant endocrine therapy with letrozole or tamoxifen in the breast international group 1-98 trial. J Clin Oncol 2012, 30:3967-3975

15. Pfeiler G, Königsberg R, Fesl C, Mlineritsch B, Stoeger H, Singer CF, Pöstlberger S, Steger GG, Seifert M, Dubsky P, Taucher S, Samonigg H, Bjelic-Radisic V, Greil R, Marth C, Gnant M: Impact of body mass index on the efficacy of endocrine therapy in premenopausal patients with breast cancer: an analysis of the prospective ABCSG-12 trial. J Clin Oncol 2011, 29:2653-2659.

16. Martin M, Rodriguez-Lescure A, Ruiz A, Alba E, Calvo L, Ruiz-Borrego M, Munárriz B, Rodríguez CA, Crespo C, de Alava E, López García-Asenjo JA, Guitián MD, Almenar S, González-Palacios JF, Vera F, Palacios J, Ramos M Gracia Marco JM, Lluch A, Alvarez I, Seguí MA, Mayordomo Jl, Antón A, Baena JM, Plazaola A, Modolell A, Pelegrí A, Mel JR, Aranda E, Adrover E, GEICAM 9906 Study Investigators, et al: Randomized phase 3 trial of fluorouracil, epirubicin, and cyclophosphamide alone or followed by Paclitaxel for early breast cancer. J Natl Cancer Inst 2008, 100:805-814.

17. Martin M, Segui MA, Anton A, Ruiz A, Ramos M, Adrover E, Aranda I, Rodríguez-Lescure A, Grosse R, Calvo L, Barnadas A, Isla D, Martinez Del Prado P, Ruiz-Borrego M, Zaluski J, Arcusa A, Muñoz M, López Vega JM, Mel JR, Munarriz B, Llorca C, Jara C, Alba E, Florián J, Li J, López García-Asenjo JA, Sáez A, Rios MJ, Almenar S, Peiró G, GEICAM 9805 Investigators, et al: Adjuvant docetaxel for high-risk, node-negative breast cancer. N Engl J Med 2010, 363:2200-2210.

18. Martin M, Pienkowski T, Mackey J, Pawlicki M, Guastalla JP, Weaver C, Tomiak E, Al-Tweigeri T, Chap L, Juhos E, Guevin R, Howell A, Fornander T, Hainsworth J, Coleman R, Vinholes J, Modiano M, Pinter T, Tang SC, Colwell B, Prady C, Provencher L, Walde D, Rodriguez-Lescure A, Hugh J, Loret C, Rupin M, Blitz S, Jacobs P, Murawsky M, Breast Cancer International Research Group 001 Investigators, et al: Adjuvant docetaxel for node-positive breast cancer. N Engl J Med 2005, 352:2302-2313.

19. Mackey JR, Martin M, Pienkowski T, Rolski J, Guastalla JP, Sami A, Glaspy J, Juhos E, Wardley A, Fornander T, Hainsworth J, Coleman R, Modiano MR,
Vinholes J, Pinter T, Rodríguez-Lescure A, Colwell B, Whitlock P, Provencher L, Laing K, Walde D, Price C, Hugh JC, Childs BH, Bassi K, Lindsay MA, Wilson V, Rupin M, Houé V, Vogel C, TRIO/BCIRG 001 investigators: Adjuvant docetaxel, doxorubicin, and cyclophosphamide in node-positive breast cancer: 10-year follow-up of the phase 3 randomised BCIRG 001 trial. Lancet Oncol 2013, 14:72-80.

20. Martín M, Ruiz A, Borrego MR, Barnadas A, González S, Calvo L, Vila MM, Antón A, Rodríguez-Lescure A, Seguí-Palmer MA, Muñoz-Mateu M, Ribugent JD, López-Vega JM, Jara C, Espinosa E, Fernández CM, Andrés R, Ribelles N, Plazaola A, Sánchez-Rovira P, Bofill JS, Crespo C, Carabantes FJ, Servitja S, Chacón Jl, Rodríguez CA, Hernando B, Alvarez I, Carrasco E, Lluch A: Fluorouracil, doxorubicin, and cyclophosphamide (FAC) versus FAC Followed by weekly paclitaxel as adjuvant therapy for high-risk, nodenegative breast cancer: results from the GEICAM/2003-02 study. J Clin Oncol 2013, 31:2593-2599.

21. World Health Organization: Global database on body mass index. BMI Classification. Table 1: The International Classification of adult underweight, overweight and obesity according to BMI. http://apps.who.int/bmi/index. jsp?introPage=intro_3.html. Access on $17^{\text {th }}$ February 2013.

22. Griggs JJ, Mangu PB, Anderson H, Balaban EP, Dignam JJ, Hryniuk WM Morrison VA, Pini TM, Runowicz CD, Rosner GL, Shayne M, Sparreboom A, Sucheston LE, Lyman GH, American Society of Clinical Oncology: Appropriate chemotherapy dosing for obese adult patients with cancer: American Society of Clinical Oncology clinical practice guideline. J Clin Oncol 2012, 30:1553-1561.

23. Bonadonna G, Valagussa P: Dose-response effect of adjuvant chemotherapy in breast cancer. N Engl J Med 1981, 304:10-15.

24. Arbuck SG IP, Setser A: Common toxicity criteria (CTC) version 2.0: highlights and tools. Annals of Oncology 1998, 9:12-12.

25. Cox DR: Regression models and life-tables (with discussion). J Royal Stat SC B 1972, 34:187-220.

26. Harrell FJ: General aspects of fitting regression models. Relaxing linearity assumption for continuous predictors. In Regression Modeling Strategies with Applications to Linear Models, Logistic Regression, and Survival Analysis. New York: Springer; 2001:16-26.

27. Dignam JJ, Wieand K, Johnson KA, Raich P, Anderson SJ, Somkin C, Wickerham DL: Effects of obesity and race on prognosis in lymph node-negative, estrogen receptor-negative breast cancer. Breast Cancer Res Treat 2006, 97:245-254.

28. Sparano JA, Wang M, Zhao F, Stearns V, Martino S, Ligibel JA, Perez EA Saphner T, Wolff AC, Sledge GW Jr, Wood WC, Davidson NE: Race and hormone receptor-positive breast cancer outcomes in a randomized chemotherapy trial. J Natl Cancer Inst 2012, 104:406-414.

29. Colleoni M, Li S, Gelber RD, Price KN, Coates AS, Castiglione-Gertsch M, Goldhirsch A, International Breast Cancer Study Group: Relation between chemotherapy dose, oestrogen receptor expression, and body-mass index. Lancet 2005, 366:1108-1110.

30. Hunter RJ, Navo MA, Thaker PH, Bodurka DC, Wolf JK, Smith JA: Dosing chemotherapy in obese patients: actual versus assigned body surface area (BSA). Cancer Treat Rev 2009, 35:69-78.

31. Rosner GL, Hargis JB, Hollis DR, Rosner GL, Hargis JB, Hollis DR, Budman DR, Weiss RB, Henderson IC, Schilsky RL: Relationship between toxicity and obesity in women receiving adjuvant chemotherapy for breast cancer: results from cancer and leukemia group B study 8541. J Clin Oncol 1996, 14:3000-3008

32. Calle EE, Kaaks R: Overweight, obesity and cancer: epidemiological evidence and proposed mechanisms. Nat Rev Cancer 2004, 4:579-591.

33. Daling JR, Malone KE, Doody DR, Johnson LG, Gralow JR, Porter PL: Relation of body mass index to tumor markers and survival among young women with invasive ductal breast carcinoma. Cancer 2001, 92:720-729.

34. Goodwin PJ, Ennis M, Pritchard KI, Trudeau ME, Koo J, Madarnas Y, Hartwick W, Hoffman B, Hood N: Fasting insulin and outcome in early-stage breast cancer: results of a prospective cohort study. J Clin Oncol 2002, 20:42-51

35. Catalano S, Marsico S, Giordano C, Mauro L, Rizza P, Panno ML, Andò S: Leptin enhances, via AP-1, expression of aromatase in the MCF-7 cell line. J Biol Chem 2003, 278:28668-28676.

36. Rose DP, Komninou D, Stephenson GD: Obesity, adipocytokines, and insulin resistance in breast cancer. Obes Rev 2004, 5:153-165.

37. McTiernan A, Rajan KB, Tworoger SS, Irwin M, Bernstein L, Baumgartner R, Gilliland F, Stanczyk FZ, Yasui Y, Ballard-Barbash R: Adiposity and sex 
hormones in postmenopausal breast cancer survivors. J Clin Oncol 2003, 21:1961-1966.

38. Gillespie EF, Sorbero ME, Hanauer DA, Sabel MS, Herrmann EJ, Weiser LJ, Jagielski $\mathrm{CH}$, Griggs JJ: Obesity and angiolymphatic invasion in primary breast cancer. Ann Surg Oncol 2010, 17:752-759.

39. Beral V: Breast cancer and hormone-replacement therapy in the Million Women Study. Lancet 2003, 362:419-427.

40. Chlebowski RT, Hendrix SL, Langer RD, Stefanick ML, Gass M, Lane D, Rodabough RJ, Gilligan MA, Cyr MG, Thomson CA, Khandekar J, Petrovitch H, McTiernan A, WHI Investigators: Influence of estrogen plus progestin on breast cancer and mammography in healthy postmenopausal women: the women's health initiative randomized trial. JAMA 2003, 289:3243-3253.

41. Kwan ML, Kushi LH, Weltzien E, Maring B, Kutner SE, Fulton RS, Lee MM, Ambrosone $C B$, Caan BJ: Epidemiology of breast cancer subtypes in two prospective cohort studies of breast cancer survivors. Breast Cancer Res 2009, 11:R31.

42. Millikan RC, Newman B, Tse CK, Moorman PG, Conway K, Dressler LG, Smith LV, Labbok MH, Geradts J, Bensen JT, Jackson S, Nyante S, Livasy C, Carey L, Earp HS, Perou CM: Epidemiology of basal-like breast cancer. Breast Cancer Res Treat 2008, 109:123-139.

doi:10.1186/bcr3572

Cite this article as: Pajares et al:: Obesity and survival in operable breast cancer patients treated with adjuvant anthracyclines and taxanes according to pathological subtypes: a pooled analysis. Breast Cancer Research 2013 15:R105.

\section{Submit your next manuscript to BioMed Central and take full advantage of:}

- Convenient online submission

- Thorough peer review

- No space constraints or color figure charges

- Immediate publication on acceptance

- Inclusion in PubMed, CAS, Scopus and Google Scholar

- Research which is freely available for redistribution 